\title{
Extraction of useful bioisostere replacments from the PDB
}

\author{
T Ritschel $^{1 *}$, DJ Wood ${ }^{1}$, J de Vlieg ${ }^{1,2}$, M Wagener $^{2}$ \\ From 6th German Conference on Chemoinformatics, GCC 2010 \\ Goslar, Germany. 7-9 November 2010
}

Bioisosteres are defined as structurally different molecules or substructures that can form similar intermolecular interactions, and therefore fragments that bind to similar protein pocket can be considered to have exhibited a degree of bioisosterism [1,2]. In this work a new method for the calculation of localized binding site similarities based on 3D-pharmacophore fingerprints is presented. The method needs no prior, time-consuming alignment of the proteins and therefore an on-the-fly searching of PDB scale crystal structure database for potential bioisosteric replacements is feasible. The binding site fingerprints are experimentally optimized to improve their performance. A variety of attributes of the fingerprints were considered in the optimization, including the placement of pharmacophore features, whether or not the fingerprints were fuzzified, and the resolution and complexity of the pharmacophore fingerprints (2-, 3- and 4-point fingerprints). Finally, fuzzy 3-point pharmacophore fingerprints were chosen to represent the optimal balance between computational resource requirements and the identification of potential replacements, and were therefore used to represent the localized binding sites in a searchable fragment database.

The utility of the approach is demonstrated by (i) separating known similar binding site pairs from random binding site pairs and (ii) a bioisosteric replacement study for fragments binding to subpockets of different proteins.

\section{Author details}

${ }^{1}$ Computational Drug Discovery Group, Center for Molecular and Biomolecular Informatics, Radboud University Nijmegen Medical Centre,

\footnotetext{
* Correspondence: t.ritschel@cmbi.ru.nl

'Computational Drug Discovery Group, Center for Molecular and Biomolecular Informatics, Radboud University Nijmegen Medical Centre, Nijmegen, The Netherlands

Full list of author information is available at the end of the article
}

Nijmegen, The Netherlands. ${ }^{2}$ Molecular Design \& Informatics, MSD, Oss, The Netherlands.

Published: 19 April 2011

References

1. Lima LM, Barreiro EJ: Bioisosterism: A Useful Strategy for Molecular Modification and Drug Design. Curr Med Chem 2005, 12:23-49.

2. Kennewell EA, Willet $P$, Ducrot $P$, Luttmann C: Identification of TargetSpecific Bioisosteric Fragments from Ligand-Protein Crystallographic Data. J Comp Aided Mol Des 2006, 20:385-394.

doi:10.1186/1758-2946-3-S1-P37

Cite this article as: Ritschel et al:: Extraction of useful bioisostere replacments from the PDB. Journal of Cheminformatics 2011 3(Suppl 1): P37.

\section{Publish with ChemistryCentral and every scientist can read your work free of charge \\ "Open access provides opportunities to our colleagues in other parts of the globe, by allowing anyone to view the content free of charge." \\ W. Jeffery Hurst, The Hershey Company. \\ - available free of charge to the entire scientific community \\ - peer reviewed and published immediately upon acceptance \\ - cited in PubMed and archived on PubMed Central \\ - yours - you keep the copyright \\ Submit your manuscript here: \\ http://www.chemistrycentral.com/manuscript/

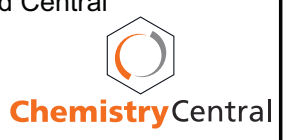

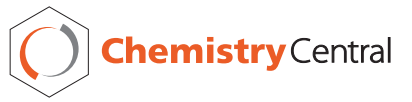

(C) 2011 Ritschel et al; licensee BioMed Central Ltd. This is an open access article distributed under the terms of the Creative Commons Attribution License (http://creativecommons.org/licenses/by/2.0), which permits unrestricted use, distribution, and reproduction in any medium, provided the original work is properly cited. 